TUGAS PENGGANTI UAS

LANDASAN ILMU PENDIDIKAN

Diajukan untuk Memenuhi Salah Satu Tugas Mata Kuliah Landasan Ilmu Pendidikan

Dosen Pembimbing

Prof. Dr. Syahrul R., M.Pd.

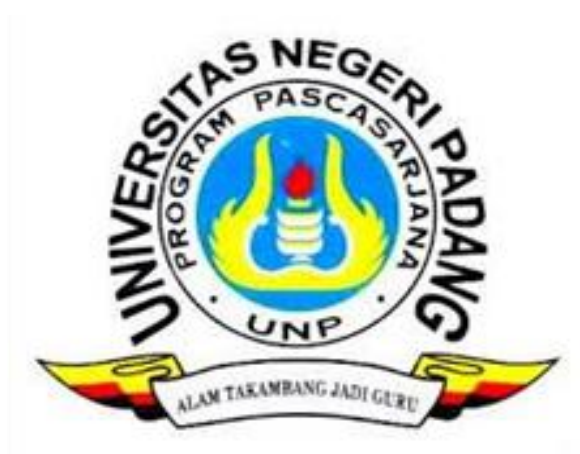

SRI YANTI

NIM 20174035

PROGRAM STUDI PENDIDIKAN BAHASA DAN SASTA INDONESIA

PROGRAM MAGISTER FAKULTAS BAHASA DAN SENI

UNIVERSITAS NEGERI PADANG

2021 


\section{Kompetensi Guru dan Kaitannya dengan Pengembangan Materi Ajar Bahasa Indonesia}

Peran guru dalam pendidikan sangatlah penting karna guru memegang tangung jawab yang besar untuk mencerdaskan generasi bangsa. Pendidikan memiliki peran urgen dalam menentukan arah perkembangan dan perwujudan diri individu. Guru bertanggung jawab mengembangakan pendidikan secara penuh, sehingga peserta didik dapat dirinya dan berfungsi sesuai kebutuhan pribadi dan masyarakat. Sudah kita ketahui bahwa sangat penting dan guru berperan penting dalam pendidikan dan pendidikan memiliki membantu peserta didik dalam mengembangkan potensi yang dimilikinya. Serta ikut berperan dalam meningkatkan keimanan dan ketakwaan serta membantu kepribadian siswa. Agusrida et al., (2020) menyatakan kompetensi profesional seorang guru dengan memiliki kompetensi antara lain dapat berkembang profesionalisme secara berkelanjutan dengan melakukan tindakan reflektif. Secara istilah guru adalah suatu komponen pendidikan dalam proses belajar mengajar yang ikut berperan dalam usaha pembentukan sumberdaya manusia yang potensial oleh karena itu, seorang guru perlu memiliki segala kompetensi yang cukup untuk pembelajaran. Kompetensi adalah suatu hal yang menggambarkan kualifikasi atau kemampuan seseorang, baik yang kualitatif maupun yang kuantitatif. Alammary (dalam Mulyadi et al., 2020:2) menyatakan bahwa lembaga pendidikan harus memberikan perhatian yang besar untuk memanfaatkan teknologi dalam proses pembelajaran, terutama dalam penggunaan bahan ajar multimedia, karena akan lebih mudah bagi pendidik untuk menjelaskan materi pembelajaran yang abstrak dan dapat dengan mudah dipahami oleh siswa.

Kegelisahan yang dirasakan guru-guru tentunya berdampak pada performa mereka dalam mengajar. Kegelisahan tersebut adalah tentang teknik dan metode mengajar apa yang seharusnya guru gunakan di dalam kelas dan bagaimana membuat siswa juga nyaman belajar dengan tuntutan kurikulum yang baru. Azar \& Hu (dalam Atmazaki et al,. 2021:379) mengemukakan menggunkan perangkat seluler dianggap sebagai alat yang efisien untuk pembelajar bahasa 
dengan dukungan tambahan untuk pemahaman dan komunikasi dan juga mengakomodasi gaya belajar yang berbeda. Morris \& Syawaludin (dalam Atmazaki et al,. 2021:3) menyatakan ketersediaan, kecanggihan, dan penggunaan perangkat tersebut berpotensi meningkatkan efisiensi dan efektivitas dalam proses belajar mengajar, hasil belajar, dan keterampilan. Keterampilan menulis, berbicara termasuk materi bahasa indonesia yang harus kembangan, dan guru harus mampu mengembangkan ametri pembeljaran tersebut agar mahasiswa mampu memahami pembeljaran yang diajarkna.

Pembelajaran bahasa Indonesia di setiap jenjang pendidikan mulai dari sekolah dasar hingga jenjang selanjutnya berorientasi pada peningkatan kemampuan berbahasa Indonesia para siswa. Penguasaan keterampilan berbahasa masih dijadikan sebagai prestasi utama dalam pembelajaran bahasa Indonesia Agustina \& Haryati (dalam Winita Sucia et al., 2019: 63). pengembangan pengetahuan dan keterampilan bahasa di sekolah menekankan pada empat keterampilan berbahasa, yaitu menyimak, berbicara, membaca, dan menulis. Keterampilan itu utuh dan saling terkait. Berkembangnya tingkat penguasaan keterampilan tentunya akan berpengaruh terhadap keterampilan berbahasa lainnya. Untuk mengembang materi ajar bahasa indonesia seorang guru harus mampu menggunkan media yang ada, untuk memudahkan pembelajaran. Erdem (dalam Ramadhan et al., 2019:2) menyatakan perlunya pengembangan profesional guru dalam literasi media digital bukanlah pilihan melainkan kewajiban. Kemajuan dalam bidang pendidikan dalam memperoleh informasi dengan menggunakan berbagai media digital tidak dapat dihindarkan.

Guru harus memiliki kompetensi dalam memilih dan menggunakan media dalam pembelajaran yang disesuaikan dengan kebutuhan siswa. Selain itu, guru juga membutuhkan literasi teknologi, memanfaatkan teknologi informasi dan komunikasi untuk berbagi informasi, menjadi model efisiensi penggunaan sumber daya teknologi. Dan Pembelajaran bahasa Indonesia merupakan pembelajaran berbasis teks Mahsun \& Hillocks (dalam Ramadhan et al., 2018:194) menyatakan Salah satu jenis teks yang dipelajari siswa di Sekolah Menengah Atas (SMA) adalah teks argumen. Menulis teks argumen adalah topik kurikuler standar di 
sekolah karena sangat penting untuk berpikir kritis dan keberhasilan akademik. Novelti et al., (2018:111) menyatakan pembelajaran Bahasa Indonesia menitik beratkan pada empat aspek keterampilan yang membutuhkan kreativitas guru untuk mencapai hasil belajar yang baik. Keempat aspek keterampilan tersebut juga diperlukan untuk mempelajari mata pelajaran lain. Setiap aspek keterampilan berbahasa Indonesia saling terkait satu sama lain. Misalnya, seseorang dapat berbicara karena ia mampu mendengarkan, atau terampil membaca, dan menulis. Demikian pula orang yang terampil menulis, jika ia terampil mendengarkan, berbicara, dan membaca. Setiap keterampilan saling terkait satu sama lain. Keterampilan berbahasa biasanya diperoleh melalui rangkaian hubungan yang teratur mulai dari mendengarkan, kemudian berbicara kemudian belajar membaca, dan menulis Tarigan (dalam Novelti et al., 2018:111) menyatakan pada urutan terakhir, menulis merupakan kegiatan yang sangat penting karena membutuhkan kreativitas dan produktivitas. 


\section{Daftar Pustaka}

Atmazaki, Syahrul, R., Vivi, I., Jeihan, N. (2020). Dialogic-Interactive Media Design for Language Learning To Improve Speaking Activities and Skills. IOP Publishing, 1-9.

Agusrida, Atmazaki, Syahrul, R., Ermanto. (2020). Effectiveness of Online Scientific Publication Training Approach for Teacher's Professional Competence Development at Religious Training Centre in Padang. Atlantis Press, 370-375.

Mulyadi, Ramadhan, S., Atmazaki, dan Agustina. (2020). The Development of EModules Based on Adobe Flash for Indonesia Subjects at IAIN Bukittinggi. IOP Publishing, 1-8.

Novelti, N., Ramadhan, S., Ermanto, E., \& Agustina, A. (2020). The Deelomment of E-Modules Based on Adobe Flash for Indonesian Subjects at IAIN Bukittinggi. Journal of Physics; Conference Series, 1471(1).

Ramadhan, S., Sukma, E., dan Indriyani, V. (2019). Teacher competence in utilizing digital media literacy in education. IOP Publishing, 1-5.

Ramadhan, S., Asri, Y., \& Indriyani, V. (2018). Learning Module Design Writing Argumentative Text Based Problem-Based Learning. . Atlantis Press . 198200.

Winita, S., Ramadhan, S., \& Asri, Y. (2019). The Development of Electronic Module Based on Discovery Learning in Writing Explanation Text. Atlantis Press, 63-69. 